\title{
Pemilihan Pemasok Dengan Mempertimbangkan Produksi Bersih/Green Manufacturing Pada Industri Otomotif
}

\author{
Johan K. Runtuk ${ }^{1}$, Anastasia L. Maukar ${ }^{2}$ \\ ${ }^{1,2)}$ Fakultas Teknik, Jurusan Teknik Industri, Universitas Presiden \\ Jababeka Educational Park, JI, Ki Hajar Dewantara, Bekasi \\ Email:johan.runtuk@president.ac.id, almaukar@gmail.com
}

\begin{abstract}
This study aims to select the best suppliers based on Fuzzy-AHP and ELECTRE methods in multinational automotive companies in Indonesia. Fuzzy AHP method is used to determine the weight of criteria and sub-criteria in reducing uncertainty and unclear information. Meanwhile, the ELECTRE method is used to rank alternative suppliers. Both methods are used to reduce subjective decisions and improve the accuracy of selected suppliers. After applying Fuzzy AHP and ELECTRE methods, the supplier chosen for the steel fuel tank is S1, for side beam impact is S2, wheel disc is S2, Seat is $S 1$, door trim is S2, lamp is S3, headlining is S3, insulator is S1 and hose is S3.
\end{abstract}

Keywords: JIT;supplier performance; Fuzzy-AHP; ELECTRE

\begin{abstract}
Abstrak
Penelitian ini bertujuan untuk memilih pemasok terbaik berdasarkan metode Fuzzy-AHP dan ELECTRE pada perusahaan otomotif multinasional di Indonesia. Metode Fuzzy AHP digunakan untuk menentukan bobot kriteria dan sub-kriteria dalam mengurangi informasi ketidakpastian dan ketidakjelasan. Sementara, metode ELECTRE digunakan untuk memberikan peringkat alternatif pemasok. Kedua metode tersebut digunakan untuk mengurangi keputusan subyektif dan meningkatkan akurasi pemasok yang dipilih. Setelah menerapkan metode Fuzzy AHP dan ELECTRE, pemasok yang dipilih untuk steel fuel tank adalah $\mathrm{S} 1$, untuk side beam impact adalah $\mathrm{S} 2$, wheel disc adalah S2, Seat adalah S1, door trim adalah S2, lamp adalah S3, headlining adalah S3, insulator adalah S1 dan hose adalah S3.
\end{abstract}

\section{Kata kunci: JIT; kinerja pemasok; Fuzzy-AHP; ELECTRE}

\section{Pendahuluan}

Aktivitas pembelian pada pabrik merupakan aktivitas yang rutin dan besar. Umumnya, pabrik konvensional menghabiskan $60 \%$ dari total penjualan untuk membeli bahan baku, suku cadang, komponen sub-perakitan, dll. Dalam industri otomotif, biayanya bahkan lebih dari $50 \%$ dari total pendapatan. Biaya dapat meningkat hingga $80 \%$ dari total biaya produksi untuk perusahaan teknologi tinggi (Yadav \& Sharma, 2015).

Kesadaran akan pentingnya peran dari departemen pembelian untuk bersaing dengan perusahaan lain menjadi perhatian di seperempat abad terakhir (Tidwell \& Sutterfield, 2012). Salah satu aspek penting dari fungsi pembelian adalah pemilihan pemasok, perolehan material, layanan dan peralatan untuk berbagai jenis bisnis. Perusahaan akan sulit untuk menghasilkan produk berkualitas tinggi dengan biaya produksi rendah tanpa pemasok yang sesuai. Dengan demikian, salah satu kegiatan pembelian yang tepat adalah pemilihan dan evaluasi pemasok yang kompeten (Yadav \& Sharma, 2016).

Pemilihan pemasok yang tepat tidak hanya berdasarkan harga yang ditawarkan, karena pemasok yang dapat menghasilkan produk dengan biaya rendah mungkin tidak memiliki kualitas terbaik dan kinerja yang baik. Oleh karena itu, divisi pembelian harus memutuskan dengan tepat kebutuhan yang harus dicapai dengan memilih pemasok (Ebrahimipour dkk., 2016).

Perusahaan otomotif bertumbuh cukup pesat di Indonesia. Saat ini, salah satu perusahaan otomotif multinasional membeli $60 \%$ dari total suku cadang untuk produksi. Perusahaan otomotif tersebut, saat ini sangat menyadari masalah lingkungan untuk produksi 
keberlanjutan. Produksi hijau atau green manufacturing menjadi bagian dari berbagai industri yang mencakup proses, teknik, praktik, atau sistem baru atau yang dimodifikasi. Gas rumah kaca, emisi berbahaya yang dihasilkan oleh pemrosesan material dan pembuangan limbah adalah bagian penting dari menciptakan pencemaran lingkungan yang dapat menyebabkan konsekuensi berbahaya bagi masa depan kita (Nukman dkk., 2017).

Dalam proses produksi dibutuhkan bahan baku yang dibeli dari pemasok. Bahan baku yang digunakan harus berkualitas agar dapat menekan jumlah cacat produk yang disebabkan oleh bahan baku, karena produk cacat akan membutuhkan pekerjaan ulang atau bahkan jadi limbah/waste. Bahan baku untuk proses produksi juga tidak boleh menciptakan pencemaran lingkungan. Oleh karena itu pemilihan pemasok bahan baku sangatlah penting dalam menciptakan produksi hijau bagi suatu perusahaan. Pembelian suku cadang untuk berproduksi ini juga harus mempertimbangkan produksi bersih/green manufacturing untuk mengurangi limbah dan menciptakan produk yang ramah terhadp lingkungan (Paul, Bhole, \& Chaulhari, 2014)

Perusahaan yang akan diteliti juga telah menerapkan sistem produksi Just-In Time (JIT), yang bertujuan untuk menghasilkan mobil dengan kualitas tinggi, harga yang wajar dan tersedia sesuai permintaan.. Sistem JIT menghilangkan salah satu waste, yaitu persediaan (Thun dkk., 2010). Agar JIT berjalan dengan lancar, kinerja pemasok untuk mengirimkan produk berdasarkan jadwal yang disediakan dan menyediakan produk berkualitas tinggi adalah hal yang sangat penting. Jika kinerja pemasok tidak dapat memenuhi standar perusahaan, maka aliran produksi akan terganggu.

Tujuan utama dari penelitian ini adalah untuk memilih pemasok terbaik dengan mempertimbangkan produksi bersih dalam menentukan kriteria dan sub-kriteria pemilihan. Sepert pada penelitian sebelumnya, Jiang (dkk) mengidentifikasi faktor-faktor kunci yang mempengaruhi pabrik otomotif Taiwan dalam pemilihan pemasok bersih/green supplier selection untuk partnya yang berguna keberlanjutan pengembangan lingkungan. Thakker \& Rane (2018) telah mengembangkan model proses green supplier development (GSD) process model dan mengimplementasikannya pada industri otomotif di India. Pemasok hijau dapat berkontribusi pada produksi yang lebih besih dan penggunaan energi yang lebih rendah.

Penelitian ini menggunakan pendekatan Multi-Criteria Decision Making (MCDM), yaitu Fuzzy Analytical Hierarchy Process (F-AHP) dan ELECTRE (Elimination Et Choice Translation Reality). F-AHP digunakan untuk memberikan bobot fuzzy untuk setiap kriteria dan sub-kriteria dalam proses seleksi dan sebagai input dalam proses ELECTRE. ELECTRE digunakan untuk memberi peringkat pemasok berdasarkan kinerja dalam kriteria yang dipertimbangkan (Charilas dkk., 2009).

\section{Material dan Metode}

\section{Penentuan Kriteria dan Sub-kriteria}

Seleksi pemasok mempertimbangkan beberapa kriteria seperti pengiriman, biaya, kualitas, layanan, dan profil perusahaan yang memerlukan beberapa metode untuk mengevaluasi serangkaian alternatif. Masalah pemilihan pemasok dikategorikan sebagai masalah pengambilan keputusan multi-kriteria (MCDM) (Kahraman dkk., 2003). Pengambilan keputusan multi-kriteria (MCDM) adalah metode terbaik untuk memilih pemasok terbaik yang memiliki risiko rendah (Chand et al., 2017). Govindan dan Jepsen (2016) mengkategorikan metode MCDM menjadi dua kelompok yaitu Multi-Attribute Decision Making (MADM) dan Multi-Objective Decision Making (MODM). MADM adalah metode untuk memecahkan serangkaian alternatif diskrit yang telah ditentukan sebelumnya. Sementara itu, MODM digunakan untuk memecahkan set alternatif yang tidak ditentukan sebelumnya. Pal dkk. (2013) mengusulkan lima metode yang dapat digunakan untuk memilih dan mengevaluasi pemasok, yaitu Methods for Prequalification of Suppliers, Multi-Attrubute Decision Making (MADM) Techniques, Mathematical Programming Models, dan Artificial Intelligence Methods.

Kriteria dan sub-kriteria pemilihan pemasok yang digunakan perusahaan saat ini akan digabungkan dengan hasil dari kajian pustaka yang berkaitan dengan green manufacturing dan hasil diskusi dengan pakar yang berasal dari phak intenal perusahaan, yaitu Kepala Divisi Pembelian. Kriteria dan sub-kriteria yang akan digunakan dalam penelitian ini dapat ditunjukkan pada Tabel 1. 
Tabel 1. Usulan Kriteria dan Sub-Kriteria Pemilihan Pemasok

\begin{tabular}{|c|c|c|c|}
\hline Kriteria & $\begin{array}{c}\text { Sub- } \\
\text { Kriteria }\end{array}$ & Deskripsi & Sumber \\
\hline \multirow[b]{2}{*}{ Price } & $\begin{array}{l}\text { Product } \\
\text { Price } \\
\text { (FT1) }\end{array}$ & $\begin{array}{l}\text { Harga yang } \\
\text { kompetitif }\end{array}$ & $\begin{array}{c}\text { Dickson } \\
(1966)\end{array}$ \\
\hline & $\begin{array}{c}\text { Cost } \\
\text { Reductio } \\
n \\
\text { Activities } \\
\text { (FT2) }\end{array}$ & $\begin{array}{l}\text { Kemampuan } \\
\text { Pemasok } \\
\text { dalam } \\
\text { mengurangi } \\
\text { biaya } \\
\end{array}$ & $\begin{array}{c}\text { Compan } \\
\text { y Expert } \\
(2018)\end{array}$ \\
\hline \multirow{4}{*}{$\begin{array}{l}\text { Compan } \\
\text { y Profile }\end{array}$} & $\begin{array}{l}\text { Geograp } \\
\text { hic } \\
\text { Location } \\
\text { (CP1) }\end{array}$ & $\begin{array}{c}\text { Lokasi } \\
\text { pemasok harus } \\
\text { berada dalam } \\
\text { jarak tertentu } \\
\text { dari fasilitas } \\
\text { perusahaan }\end{array}$ & $\begin{array}{c}\text { Dickson } \\
\text { (1966), } \\
\text { Weber } \\
\text { dkk. } \\
\text { (1991), } \\
\text { Cheragi } \\
\text { dkk. } \\
\text { (2004), } \\
\text { Tektas \& } \\
\text { Aytekin } \\
\text { (2011), } \\
\text { Chan } \\
\text { dkk. } \\
(2008) \\
\end{array}$ \\
\hline & $\begin{array}{c}\text { Compan } \\
y \\
\text { Structure } \\
\text { (CP2) }\end{array}$ & $\begin{array}{l}\text { Pemasok yang } \\
\text { memiliki } \\
\text { struktur } \\
\text { organisasi } \\
\text { lengkap untuk } \\
\text { mendukung } \\
\text { sistem } \\
\text { produksi, } \\
\text { Quality, } R \& D \\
\text { Department, dll } \\
\end{array}$ & $\begin{array}{c}\text { Beskase } \\
\text { \& Sakra } \\
(2010)\end{array}$ \\
\hline & $\begin{array}{l}\text { Collabor } \\
\text { ation } \\
\text { Duration } \\
\text { (CP3) }\end{array}$ & $\begin{array}{c}\text { Pemasok yang } \\
\text { memiliki } \\
\text { hubungan kuat } \\
\text { dengan } \\
\text { perusahaan } \\
\end{array}$ & $\begin{array}{c}\text { Tektas \& } \\
\text { Aytekin } \\
(2011)\end{array}$ \\
\hline & $\begin{array}{l}\text { Perform } \\
\text { ance } \\
\text { History/ } \\
\text { Experien } \\
\text { ce } \\
\text { (CP4) }\end{array}$ & $\begin{array}{c}\text { Pemasok } \\
\text { memiliki kinerja } \\
\text { yang baik } \\
\text { dalam kualitas, } \\
\text { keamanan, } \\
\text { pengiriman, } \\
\text { dan lingkungan } \\
\text { dan memiliki } \\
\text { pengalaman } \\
\text { dalam melayani } \\
\text { industri otomotif } \\
\end{array}$ & $\begin{array}{c}\text { Dickson } \\
(1966), \\
\text { Weber } \\
\text { dkk. } \\
\text { (1991), } \\
\text { Cheragi } \\
\text { dkk. } \\
(2004)\end{array}$ \\
\hline \multirow{3}{*}{$\begin{array}{l}\text { Safety } \\
\text { and } \\
\text { Environ } \\
\text { mental } \\
\text { Concem }\end{array}$} & $\begin{array}{c}\text { ISO } \\
14001 \\
\text { Certificat } \\
\text { ion } \\
\text { (SE1) } \\
\end{array}$ & $\begin{array}{l}\text { Pemasok yang } \\
\text { peduli tentang } \\
\text { sistem } \\
\text { lingkungan }\end{array}$ & $\begin{array}{c}\text { Tektas \& } \\
\text { Aytekin } \\
(2011)\end{array}$ \\
\hline & $\begin{array}{l}\text { Use of } \\
\text { Environ } \\
\text { mentally- } \\
\text { friendly } \\
\text { products } \\
\text { (SE2) }\end{array}$ & $\begin{array}{l}\text { Pemasok yang } \\
\text { peduli tentang } \\
\text { Sistem Data } \\
\text { Material } \\
\text { Internasional } \\
\text { (IMDS) untuk } \\
\text { industri otomotif }\end{array}$ & $\begin{array}{c}\text { Tektas \& } \\
\text { Aytekin } \\
(2011)\end{array}$ \\
\hline & $\begin{array}{c}\text { Safety } \\
\text { Records } \\
\text { (SE3) }\end{array}$ & $\begin{array}{c}\text { Jumlah } \\
\text { kecelakaan } \\
\text { fatal yang } \\
\text { terjadi di lantai } \\
\text { toko pemasok }\end{array}$ & $\begin{array}{c}\text { Dickson } \\
(1966)\end{array}$ \\
\hline
\end{tabular}

\begin{tabular}{|c|c|c|c|}
\hline Kriteria & $\begin{array}{c}\text { Sub- } \\
\text { Kriteria }\end{array}$ & Deskripsi & Sumber \\
\hline & $\begin{array}{c}\text { Safety } \\
\text { Activity } \\
\text { (SE4) }\end{array}$ & $\begin{array}{c}\text { Pemasok } \\
\text { memiliki } \\
\text { aktivitas } \\
\text { keselamatan } \\
\text { untuk } \\
\text { mencegah } \\
\text { kecelakaan di } \\
\text { area produksi } \\
\end{array}$ & $\begin{array}{c}\text { Compan } \\
\text { y Expert } \\
(2018)\end{array}$ \\
\hline \multirow[t]{2}{*}{ Delivery } & $\begin{array}{c}\text { On-Time } \\
\text { Delivery } \\
\text { (DV1) }\end{array}$ & $\begin{array}{c}\text { Keakuratan } \\
\text { pemasok dalam } \\
\text { memenuhi } \\
\text { waktu } \\
\text { pengiriman } \\
\text { yang dijanjikan }\end{array}$ & $\begin{array}{c}\text { Dickson } \\
\text { (1966), } \\
\text { Weber } \\
\text { dkk. } \\
(1991), \\
\text { Cheragi } \\
\text { dkk. } \\
\text { (2004), } \\
\text { Tektas \& } \\
\text { Aytekin } \\
\text { (2011), } \\
\text { Beskase } \\
\text { \& Sakra } \\
\text { (2010) }\end{array}$ \\
\hline & $\begin{array}{l}\text { Complia } \\
\text { nce with } \\
\text { the } \\
\text { specifica } \\
\text { tions } \\
\text { (DV2) }\end{array}$ & $\begin{array}{l}\text { Pemasok harus } \\
\text { mengirimkan } \\
\text { produk } \\
\text { berdasarkan } \\
\text { spesifikasi yang } \\
\text { ditentukan } \\
\end{array}$ & $\begin{array}{c}\text { Compan } \\
\text { y Expert } \\
(2018)\end{array}$ \\
\hline \multirow{3}{*}{$\begin{array}{c}\text { Capabilit } \\
\text { ies }\end{array}$} & $\begin{array}{l}\text { Producti } \\
\text { on } \\
\text { Capabilit } \\
y(C B 1)\end{array}$ & $\begin{array}{l}\text { Kemampuan } \\
\text { dalam } \\
\text { memenuhi } \\
\text { permintaan } \\
\text { meskipun } \\
\text { menghadapi } \\
\text { lonjakan dan } \\
\text { ketidakpastian } \\
\end{array}$ & $\begin{array}{c}\text { Beskase } \\
\text { \& Sakra } \\
(2010)\end{array}$ \\
\hline & $\begin{array}{c}\text { Producti } \\
\text { on } \\
\text { Facilities } \\
\text { (CB2) }\end{array}$ & $\begin{array}{c}\text { Kemampuan } \\
\text { fasilitas } \\
\text { pemasok untuk } \\
\text { memenuhi } \\
\text { permintaan } \\
\text { pelanggan }\end{array}$ & $\begin{array}{c}\text { Dickson } \\
\text { (1966), } \\
\text { Weber } \\
\text { dkk. } \\
(1991), \\
\text { Cheragi } \\
\text { dkk. } \\
(2004) \\
\end{array}$ \\
\hline & $\begin{array}{c}\text { Technica } \\
\text { I } \\
\text { Capabilit } \\
y(C B 3)\end{array}$ & $\begin{array}{c}\text { Kemampuan } \\
\text { pemasok dalam } \\
\text { menyediakan } \\
\text { teknologi } \\
\text { canggih } \\
\end{array}$ & $\begin{array}{c}\text { Dickson } \\
\text { (1966), } \\
\text { Cheragi } \\
\text { dkk. } \\
(2004)\end{array}$ \\
\hline Quality & $\begin{array}{c}\text { Product } \\
\text { Quality } \\
\text { (QT1) }\end{array}$ & $\begin{array}{c}\text { Pemasok yang } \\
\text { dapat } \\
\text { menyediakan } \\
\text { produk } \\
\text { berkualitas baik } \\
\text { yang memenuhi } \\
\text { harapan } \\
\text { perusahaan }\end{array}$ & $\begin{array}{c}\text { Dickson } \\
\text { (1966), } \\
\text { Weber } \\
\text { dkk. } \\
\text { (1991), } \\
\text { Cheragi } \\
\text { dkk. } \\
\text { (2004), } \\
\text { Tektas \& } \\
\text { Aytekin } \\
\text { (2011), } \\
\text { Beskase } \\
\text { \& Sakra } \\
\text { (2010), } \\
\text { Chan } \\
\text { dkk. } \\
\text { (2008) }\end{array}$ \\
\hline
\end{tabular}




\begin{tabular}{|c|c|c|c|}
\hline Kriteria & $\begin{array}{c}\text { Sub- } \\
\text { Kriteria }\end{array}$ & Deskripsi & Sumber \\
\hline & $\begin{array}{c}\text { Quality } \\
\text { Awards/ } \\
\text { Certificat } \\
\text { es (QT2) }\end{array}$ & $\begin{array}{c}\text { Pemasok } \\
\text { memiliki kinerja } \\
\text { berkualitas baik } \\
\text { yang dapat } \\
\text { ditunjukkan dari } \\
\text { sertifikat } \\
\text { kualitasnya }\end{array}$ & $\begin{array}{c}\text { Tektas \& } \\
\text { Aytekin } \\
(2011)\end{array}$ \\
\hline & $\begin{array}{l}\text { ISO } \\
9000 \\
\text { (QT3) }\end{array}$ & $\begin{array}{c}\text { Pemasok harus } \\
\text { memiliki } \\
\text { Sertifikat ISO } \\
9000 \text { untuk } \\
\text { memastikan } \\
\text { kualitas proses } \\
\text { dan produk } \\
\end{array}$ & $\begin{array}{c}\text { Beskase } \\
\text { \& Sakra } \\
(2010)\end{array}$ \\
\hline \multirow{2}{*}{ Services } & $\begin{array}{c}\text { Informati } \\
\text { on } \\
\text { Sharing } \\
\text { (SV1) }\end{array}$ & $\begin{array}{c}\text { Kemudahan } \\
\text { komunikasi dan } \\
\text { berbagi } \\
\text { informasi } \\
\text { dengan } \\
\text { perusahaan }\end{array}$ & $\begin{array}{c}\text { Tektas \& } \\
\text { Aytekin } \\
(2011), \\
\text { Chan } \\
\text { dkk. } \\
(2008) \\
\end{array}$ \\
\hline & $\begin{array}{l}\text { Flexibilit } \\
y \text { and } \\
\text { Respons } \\
\text { iveness } \\
\text { (SV2) }\end{array}$ & $\begin{array}{c}\text { Kemampuan } \\
\text { pemasok untuk } \\
\text { berubah sesuai } \\
\text { dengan } \\
\text { permintaan } \\
\text { pelanggan } \\
\end{array}$ & $\begin{array}{c}\text { Beskase } \\
\text { \& Sakra } \\
(2010)\end{array}$ \\
\hline
\end{tabular}

Dalam penelitian ini, untuk memilih pemasok yang memiliki lebih dari satu kriteria, metode AHP dengan Fuzzy digunakan untuk mengurangi ketidakpastian, bias, dan ketidakjelasan informasi, untuk mengekspresikan kenyataan. Fuzzy AHP akan digunakan untuk menentukan bobot kriteria dan sub-kriteria. Kemudian Fuzzy AHP akan digabung dengan metode ELECTRE untuk menentukan peringkat pemasok.

\section{Metode Fuzzy Analytical Hierarchy Process (F-AHP)}

F-AHP adalah kombinasi dari logika fuzzy dan analisis struktur hierarki. Fuzzy Analytical Hierarchy Process (F-AHP) merupakan metode AHP digunakan untuk memutuskan dengan lebih dari satu kriteria atau disebut pengambilan keputusan multi-kriteria. F-AHP menggunakan perbandingan pasangan dan alat keputusan untuk kriteria yang berbeda dengan beberapa kriteria. Dalam AHP tradisional, tingkat pertama hirarki menggambarkan kriteria, sedangkan kriteria dan sub-kriteria akan berada di tingkat kedua dan ketiga. Terakhir, alternatif akan ditemukan di tingkat keempat. AHP tradisional tidak memasukkan ketidakpastian dan ambiguitas. Dengan demikian metode ini ditingkatkan dengan menggunakan logika fuzzy. Dalam FAHP perbandingan berpasangan akan dilakukan menggunakan variabel linguistik. Variabel linguistik dijelaskan dengan angka segitiga (Ayhan, 2013).

Langkah F-AHP untuk menghitung kriteria dan bobot sub-kriteria adalah:

Langkah 1: Memecah masalah ke dalam struktur hierarki AHP

Langkah 2: Melakukan perbandingan berpasangan menggunakan istilah linguistik yang ditunjukkan pada Tabel 2 .

Tabel 2. Skala Linguistic Terms dan Fuzzy Triangular

\begin{tabular}{|c|c|c|}
\hline $\begin{array}{c}\text { Skala } \\
\text { Saaty }\end{array}$ & Deskripsi & $\begin{array}{c}\text { Fuzzy } \\
\text { Triangular } \\
\text { Scale }\end{array}$ \\
\hline 1 & Equally Important & $(1,1,1)$ \\
\hline 3 & Weakly Important & $(2,3,4)$ \\
\hline 5 & Fairly Important' & $(4,5,6)$ \\
\hline 7 & Strongly Important & $(6,7,8)$ \\
\hline 9 & $\begin{array}{c}\text { Absolutely } \\
\text { Important }\end{array}$ & $(9,9,9)$ \\
\hline 2 & \multirow{2}{*}{$\begin{array}{c}\text { The Intermittent } \\
\text { values between two } \\
\text { adjacent scales }\end{array}$} & $(1,2,3)$ \\
\cline { 1 - 1 } & $(3,4,5)$ \\
\cline { 1 - 1 } 6 & $(7,6,7)$ \\
\hline 8 & &
\end{tabular}

Berdasarkan Tabel 2. istilah linguistik memiliki keterkaitan dengan skala segitiga fuzzy, misalnya, jika kriteria $A(C A)$ Cukup Penting untuk kriteria $B$ (CB) maka matriks perbandingan pasangan adalah 5 . Persamaan (1) untuk kontribusi berpasangan matriks ,

$$
\tilde{A}^{k}=\left[\begin{array}{cccc}
\tilde{d}_{11}^{k} & \tilde{d}_{12}^{k} & \ldots & \tilde{d}_{1 n}^{k} \\
\tilde{d}_{21}^{k} & \ldots & \ldots & \tilde{d}_{2 n}^{k} \\
\ldots & \ldots & \ldots & \ldots \\
\tilde{d}_{n 1}^{k} & \tilde{d}_{n 2}^{k} & \ldots & \tilde{d}_{n n}^{k}
\end{array}\right] \text { Pers.1 }
$$

Dari Persamaan (1), $\widetilde{d}_{l j}^{k} \quad$ menunjukkan preferensi pemimpin ke-k dari kriteria ke-j.

Langkah 3: Tentukan rata-rata geometrik dari matriks perbandingan pasangan dengan menggunakan Persamaan (2)

$\tilde{r}_{1}=\left(\prod_{j=1}^{n} \widetilde{d_{l \jmath}}\right)^{1 / n}, i=1,2, \ldots, n$

Pers.2

Langkah 4: Tentukan rasio konsistensi untuk mengevaluasi perbandingan berpasangan secara konsisten atau tidak. Untuk menentukan rasio konsistensi, langkah pertama yang harus dilakukan adalah dengan menghitung vektor eigen dan nilai eigen dalam Persamaan (3) dan Persamaan (4).

$$
\begin{array}{rr}
W_{1}=\frac{1}{n} \sum_{j=7}^{j=1} \frac{a_{11}}{x_{1}}+\cdots+\frac{a_{16}}{x_{6}} & \text { Pers.3 } \\
\lambda_{\max }=W_{i} \times x_{i} & \text { Pers.4 }
\end{array}
$$


Perhitungan indeks konsistensi menggunakan Persamaan (5), kemudian menghitung rasio konsistensi dengan Persamaan (6).

$$
\begin{aligned}
& C I=\frac{\lambda \max -n}{n-1} \\
& C R=\frac{C I}{R I}
\end{aligned}
$$

Pers.5

Pers.6

Jika CR lebih dari 0,1 artinya perbandingan berpasangan tidak konsisten, tidak dapat diandalkan, dan tidak dapat digunakan untuk penelitian lebih lanjut.

Langkah 5: Setelah menghitung rasio konsistensi, langkah selanjutnya adalah mengubah matriks perbandingan berpasangan menjadi perbandingan segitiga fuzzy pada Tabel 2. Persamaan (7) untuk menghitung matriks kontribusi berpasangan.

$$
\tilde{A}^{k}=\left[\begin{array}{cccc}
1 & \tilde{d}_{12}^{k} & \ldots & \tilde{d}_{1 n}^{k} \\
\frac{1}{\tilde{d}_{12}^{k}} & 1 & \ldots & \tilde{d}_{2 n}^{k} \\
\ldots & \ldots & \ddots & \ldots \\
\frac{1}{\tilde{d}_{n 1}^{k}} & \frac{1}{\tilde{d}_{n 2}^{k}} & \ldots & 1
\end{array}\right] \quad \text { Pers.7 }
$$

Langkah 6: Untuk lebih dari satu pengambil keputusan, preferensi akan dirata-rata yang dihitung dengan menggunakan Persamaan (8).

$$
\widetilde{d_{\imath \jmath}}=\frac{\sum_{k=1}^{k} \widetilde{d_{l j}^{k}}}{k}
$$

Pers.8

Langkah 7: Berdasarkan preferensi rata-rata yang telah dihitung pada langkah 2 , kontribusi berpasangan baru dapat ditunjukkan pada Persamaan (9)

$$
\tilde{A}=\left(\begin{array}{ccc}
\widetilde{d_{11}} & \cdots & \widetilde{d_{1 n}} \\
\vdots & \ddots & \vdots \\
\widetilde{d_{n 1}} & \cdots & \widetilde{d_{n n}}
\end{array}\right)
$$

Pers.9

Langkah 8: Rerata geometris kriteria perbandingan fuzzy dapat dihitung menggunakan Persamaan (2)

Langkah 9: Temukan penjumlahan vektor masing-masing $\tilde{r}_{1}$.. Temukan $(-1)$ kekuatan vektor ummation. Ganti nomor segitiga fuzzy, untuk membuatnya dalam urutan yang meningkat. Bobot fuzzy dari setiap kriteria dapat ditemukan menggunakan Persamaan (10)

$$
\begin{aligned}
& \widetilde{w_{l}}=\tilde{r}_{i} \otimes\left(\tilde{r}_{1} \oplus \tilde{r}_{2} \oplus \cdots \oplus \tilde{r}_{n}\right)^{-1} \\
& \widetilde{w_{l}}=\left(l w_{i}, m w_{i}, u w_{i}\right) \quad \text { Pers.10 }
\end{aligned}
$$

Langkah 10: Hasil langkah 5 adalah angka segitiga fuzzy. Dengan demikian, kebutuhannya untuk tidak di-fuzzifikasi yang ditunjukkan pada Persamaan (11)

$$
M_{i}=\frac{l w_{i}+m w_{i}+u w_{i}}{3}
$$

Pers.11

Langkah 11: Hasil perhitungan pada langkah 6 masih pada angka non-fuzzy. Dinormalisasi dengan Persamaan (12)

$$
N_{i}=\frac{M_{i}}{\sum_{i=1}^{n} M_{i}}
$$

11 langkah ini digunakan untuk menghitung bobot yang dinormalisasi. Hasil tertinggi $N_{i}$ akan disarankan kepada pembuat keputusan atau pemimpin itu sendiri.

\section{Elimination and Choice Expressing Reality (ELECTRE)}

Metode ELECTRE diusulkan oleh Benayoun, Roy, dan Sussman. Kemudian, berganti nama menjadi ELECTRE-I pada tahun 1968. Beberapa metode dikembangkan selama dua dekade terakhir yaitu ELECTRE-II, ELECTRE III, ELECTRE IV, ELECTRE TRI, dan ELECTRE IS. Semua metode ELECTRE termasuk metode outranking (Govindan \& Jepsen, 2016). Metode ELECTRE dapat digunakan untuk memberi peringkat pemasok. Mempertimbangkan $A_{1}, A_{2}, \ldots, A_{m}$ adalah alternatif yang mungkin, $C_{1}, C_{2}, \ldots, C_{n}$ adalah kriteria dengan mana kinerja alternatif diukur, $x_{i j}$ adalah peringkat dari alternatif $A_{i}$ sehubungan dengan kriteria $C_{j}$. Langkahlangkah ELECTRE untuk menentukan peringkat kelompok pemasok dijelaskan sebagai berikut:

Langkah 1: Tetapkan matriks data $\left[\mathrm{x}_{\mathrm{ij}}\right]$ yang menunjukkan matriks data pemasok untuk setiap kriteria seperti pada Persamaan (13)

$x_{i j}=\left[\begin{array}{cccc}x_{11} & x_{12} & \ldots & x_{1 n} \\ x_{21} & x_{22} & \ldots & x_{2 n} \\ \vdots & \vdots & \vdots & \vdots \\ x_{m 1} & x_{m 1} & \cdots & x_{m n}\end{array}\right]$

Pers.13

Dari matriks di atas, kriteria keputusan dilambangkan dengan $(\mathrm{n})$ dan alternatif baris dilambangkan dengan $\mathrm{m}$.

Langkah 2: Normalisasi matriks data menggunakan Persamaan (14)

$$
\begin{array}{r}
R=\left[r_{i j}\right]_{m * n}, r i j=\frac{r_{i j}}{\sqrt{\sum_{i=1}^{m} r_{i j}^{2}}} i=1, \ldots, m ; j= \\
1, \ldots, n \text { Pers.14 }
\end{array}
$$

Langkah 3: Buat matriks tertimbang (weighted matrix). Pada langkah ini, bobot kriteria dihitung untuk menentukan pemasok yang dipilih. Matriks bobot (V) dapat dihitung dengan 
mengalikan matriks data yang dinormalisasi dengan bobot yang telah dihitung dalam FAHP (lihat Persamaan (15)_.

$$
V=\left[V_{i j}\right]_{m * n} ; V_{i j}=\left\lceil w_{j} r_{i j}\right\rceil \quad \text { Pers.15 }
$$

Langkah 4: Membangun Himpunan Konkordansi dan Perselisihan (Concordance and Discordance Set) Konkordansi terdiri dari semua atribut untuk Alternatif Ak sama atau lebih baik daripada $A_{l}$ yang dapat ditampilkan pada Persamaan (16)

$$
C(k, l)=\{j, V k j \geq V l j\} \quad \text { Pers.16 }
$$

Dalam persamaan di atas, $V^{\mathrm{kj}}$ adalah skor tertimbang (weighted score) dari $A_{p}$ alternatif sehubungan dengan atribut j. Set discorcondace yang merupakan kebalikan dari $D(k, I)$, berisi semua atribut yang $A_{l}$ lebih baik daripada $A_{k}$. Ini dapat ditampilkan sebagai Persamaan (17)

$$
D(k, l)=\{j, V k j<V l j\}
$$

Pers.17

Langkah 5: Hitung Concordance dan Discordance Index

Indeks kesesuaian dapat dihitung dengan Persamaan (18).

$$
C_{k l}=\sum_{j \in C_{k l}} W_{j}
$$

Pers.18

Dimana $j$ * adalah atribut yang termasuk dalam set konkordansi $\mathrm{C}(\mathrm{k}, \mathrm{I})$. Sedangkan indeks ketidaksesuaian/discorcondance dapat dihitung dengan Persamaan (19).

$$
d_{k l}=\frac{\max \left\{\left|v_{k j}-v_{i j}\right|\right\}_{j \in d_{k l}}}{\max \left\{\left|v_{k j}-v_{i j}\right|\right\} \forall j}
$$

Pers.19

Langkah 6: Tentukan nilai ambang

Pada langkah ini, ambang konkordansi dan ketidaksesuaian harus ditentukan dengan menghitung rata-rata konkordansi dan indeks ketidaksesuaian.

Langkah 7: Tentukan hubungan outranking Langkah terakhir dari metode ELECTRE menentukan hubungan outranking. Hubungan dominan dari alternatif $A_{k}$ ke $A_{l}$ menjadi lebih kuat dengan konkordansi di atas ambang (threshold) C dan ketidaksesuaian (discordance)yang lebih rendah dari ambang $D$ $\left(C_{k l} \geq C\right.$ * dan $\left.D_{k l}<D *\right)$

\section{Langkah-lankah Penelitian}

Langkah-langkah penelitian disajikan pada Gambar 1. Dalam penelitian ini menggunakan kombinasi kriteria dan sub-kriteria dari hasil kajian pustka dan kriteria dan sub-kriteria pemilihan pemasok yang saat ini telah digunakan oleh perusahaan. Ada Tujuh kriteria akan digunakan dalam memilih pemasok berdasarkan green manufacturing, yaitu: cost, company profile, safety, and environmental concern, delivery, capability, quality, dan services. Setiap kriteria memiliki sub-kriteria seperti untuk biaya sub-kriteria seperti tercantum pada Tabel 1.

Kuesioner disebarkan untuk untuk menentukan bobot kriteria, sub-kriteria dan kandidat pemasok. Kuesioner disebarkan kepada delapan responden, yaitu beberapa kepala bagian dari Divisi Pembelian.

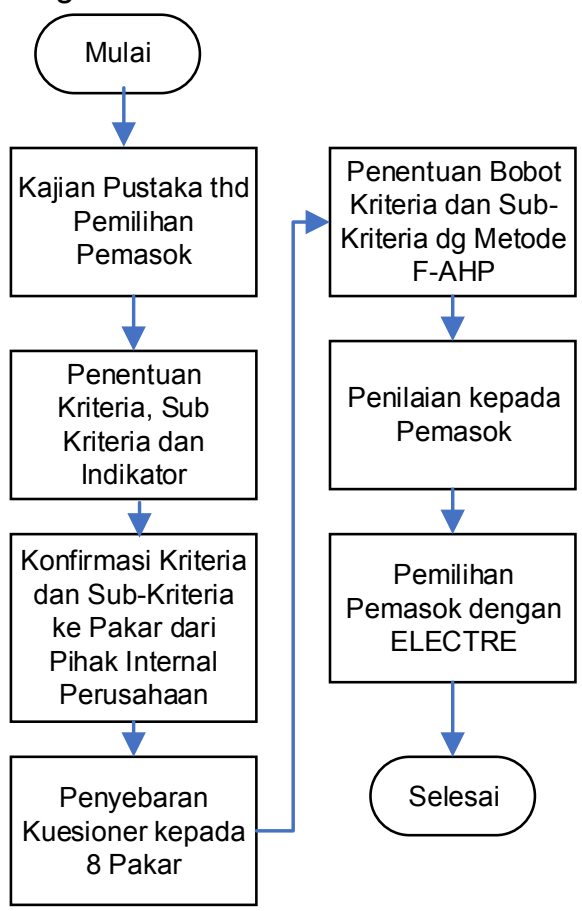

Gambar 1. Diagram Alir Langkah Penelitian

\section{Hasil dan Pembahasan}

\section{Perhitungan Bobot Kriteria dan Sub-Kriteria}

Dari kuesioner yang telah disebarkan kepada delapan orang pakar yaitu Kepala Bagian Divisi Pembelian yang bertugas melakukan pemilihan pemasok part-part dan bertugas untuk menyediakan data pemasok. Bobot kriteria dan sub-kriteria akan dihitung menggunakan metode Fuzzy-AHP yang berasal dari perbandingan berpasangan antara kriteria dan sub-kriteria, Rasio konsistensi (CR) yang diijinkan harus kurang dari 0,10 atau $10 \%$. CR untuk sub-kriteria biaya adalah 0 , profil perusahaan adalah 0,062, keselamatan dan lingkungan adalah 0,0217 , pengiriman adalah 0, kemampuan 0,0025, kualitas 0,0476, dan layanan adalah 0 . Semua CR kurang dari 0,1 yang menunjukkan bahwa data cukup konsisten. Hasil perhitungan bobot dapat 
dilihat pada Tabel 3. Bobot global adalah bobot yang akan digunakan dalam penelitian ini. Bobot global dihitung dengan perkalian bobot kriteria yang dinormalisasi dan bobot sub-kriteria yang dinormalisasi.

Tabel 3. Bobot Global dariKriteria dan Su-Kriteria

\begin{tabular}{|c|c|c|c|c|c|c|}
\hline Kriteria & Relat & Fuzzy V & ight & Mi & $\mathbf{N i}$ & Bo \\
\hline Cost & 0.0273 & 0.041 & 0.0622 & 0.0435 & 0.0408 & \\
\hline FT1 & 0.3352 & 0.3804 & 0.4274 & 0.381 & 0.3799 & 0.0155 \\
\hline FT2 & 0.5736 & 0.6196 & 0.6729 & 0.622 & 0.6201 & 0.0253 \\
\hline CP1 & 0.0546 & 0.078 & 0.1085 & 0.0804 & 0.0784 & 0.0001 \\
\hline CP2 & 0.1912 & 0.2758 & 0.3837 & 0.2836 & 0.2766 & 0.0003 \\
\hline CP3 & 0.1382 & 0.1582 & 0.1909 & 0.1624 & 0.1584 & 0.0002 \\
\hline CP4 & 0.3766 & 0.488 & 0.6318 & 0.4988 & 0.4866 & 0.0006 \\
\hline Safety \& Environment & 0.0882 & 0.1427 & 0.2225 & 0.1512 & 0.1418 & \\
\hline SE1 & 0.3613 & 0.4178 & 0.493 & 0.424 & 0.4188 & 0.0594 \\
\hline SE2 & 0.0611 & 0.0654 & 0.073 & 0.0665 & 0.0657 & 0.0093 \\
\hline SE3 & 0.1498 & 0.1988 & 0.2444 & 0.1977 & 0.1953 & 0.0277 \\
\hline SE4 & 0.2527 & 0.3181 & 0.4019 & 0.3242 & 0.3202 & 0.0454 \\
\hline Delivery & 0.1688 & 0.2646 & 0.4139 & 0.2824 & 0.265 & \\
\hline DV1 & 0.5611 & 0.5778 & 0.5956 & 0.5782 & 0.5779 & 0.1531 \\
\hline DV2 & 0.4024 & 0.4222 & 0.4424 & 0.4223 & 0.4221 & 0.1118 \\
\hline Capability & 0.1556 & 0.2343 & 0.3575 & 0.2492 & 0.2337 & \\
\hline CB1 & 0.4953 & 0.575 & 0.6459 & 0.5721 & 0.5693 & 0.1331 \\
\hline CB2 & 0.1808 & 0.1966 & 0.2385 & 0.2053 & 0.2043 & 0.0478 \\
\hline CB3 & 0.211 & 0.2284 & 0.2429 & 0.2274 & 0.2263 & 0.0529 \\
\hline Quality & 0.1648 & 0.2688 & 0.4328 & 0.2888 & 0.2709 & \\
\hline QT1 & 0.2738 & 0.3485 & 0.4185 & 0.3469 & 0.3963 & 0.1074 \\
\hline QT2 & 0.1664 & 0.1721 & 0.1896 & 0.176 & 0.2011 & 0.0545 \\
\hline QT3 & 0.3156 & 0.3495 & 0.3919 & 0.3523 & 0.4025 & 0.1091 \\
\hline Service & 0.037 & 0.0473 & 0.0643 & 0.0496 & 0.0465 & \\
\hline SV1 & 0.6646 & 0.6884 & 0.7106 & 0.6879 & 0.6981 & 0.0325 \\
\hline SV2 & 0.3072 & 0.2958 & 0.2894 & 0.2975 & 0.3019 & 0.014 \\
\hline
\end{tabular}

\section{Penilaian dan Pemilihan Pemasok}

Pemasok akan dinilai menggunakan penilaian rubrik pada formulir kinerja Januari Mei 2018. Perusahaan mengelompokkan pemasok menjadi tiga kelompok berdasarkan jenis produk, yaitu baja/steel, resin, dan karet/rubber. Dalam penelitian ini, akan ada tiga part untuk setiap produk yang akan menjadi sampel penelitian ini. Sampel produk baja adalah tangki bahan bakar baja/Steel Fuel Tank, side beam impact dan wheel disc. Untuk produk resin sampelnya adalah seat, door trim, dan bagian lampu/lamp. Sedangkan untuk produk karet, sampelnya adalah headlining, dash insulator dan hose.

Setelah bobot kriteria dan sub-kriteria telah ditentukan menggunakan Metode Fuzzy AHP, bobot digunakan untuk menentukan, bobot akan digunakan untuk menentukan pemasok yang akan dipilih. Kemudian bobot akan digunakan sebagai input untuk metode ELECTRE. Langkah perhitungan ELECTRE dimulai dari normalisasi matriks data pemasok, menghitung matriks tertimbang yang dinormalisasi, menentukan himpunan konkordansi dan himpunan ketidaksesuaian, menghitung indeks konkordansi dan ketidaksesuaian dan terakhir menentukan hubungan outranking.

Lampiran A menunjukkan matriks data pemasok. Kemudaian data matriks tersebut akan telah dinormalisasi dengan menggunakan Persamaan (14). Hubungan dominasi alternatif $A$ atas $B$ menjadi lebih kuat jika indeks kesesuaian lebih tinggi dari ambang $C^{*}$ dan ketidaksesuaian/discordance lebih rendah dari $D^{*}$. Ambang $C$ * dan ambang $D$ * untuk masing-masing produk dapat ditunjukkan pada Tabel 4.

Setelah menghitung indeks kesesuaian, indeks ketidaksesuaian, ambang $D$ *, dan ambang $C^{*}$, ini adalah langkah terakhir dari metode ELECTRE untuk menentukan pemasok terbaik untuk setiap part dari ketiga jenis produk (Resin, Rubber dan Steel) yang merupakan penentuan hubungan outranking. Hubungan outranking untuk semua part dapat dilihat pada Lampiran B. 
Tabel 4. Perhitungan Ambang $C^{*}$ dan $D^{*}$

\begin{tabular}{|c|c|c|c|}
\hline Comm. & \multicolumn{3}{|c|}{ Steel } \\
\hline Part & $\begin{array}{c}\text { Steel Fuel } \\
\text { Tank }\end{array}$ & $\begin{array}{c}\text { Side } \\
\text { Beam } \\
\text { Impact }\end{array}$ & $\begin{array}{c}\text { Wheel } \\
\text { Disc }\end{array}$ \\
\hline $\mathrm{C}^{*}$ & 0.709 & 0.6754 & 0.6754 \\
\hline $\mathrm{D}^{*}$ & 0.5639 & 0.5998 & 0.5998 \\
\hline Comm. & \multicolumn{3}{|c|}{ Resin } \\
\hline Part & Seat & $\begin{array}{c}\text { Door } \\
\text { Trim }\end{array}$ & Lamp \\
\hline $\mathrm{C}^{*}$ & 0.6564 & 0.6554 & 0.7252 \\
\hline $\mathrm{D}^{*}$ & 0.5641 & 0.6826 & 0.717 \\
\hline Comm. & \multicolumn{3}{|c|}{ Rubber } \\
\hline Part & Headlining & Insulator & Hose \\
\hline $\mathrm{C}^{*}$ & 0.6963 & 0.7209 & 0.7153 \\
\hline $\mathrm{D}^{*}$ & 0.6763 & 0.5639 & 0.5559 \\
\hline
\end{tabular}

Berdasarkan Lampiran B akan dilakukan evaluasi hubungan outranking antara masingmasing pemasok dengan meminjau indeks kesesuaian dan ambang $C$ *, dan indeks ketidaksesuaian dan ambang $D$ *. Ringkasan pemasok yang dipilih berdasarkan part dapat ditunjukkan pada Tabel 5.

Tabel 5. Pemasok Terpilih untuk Setiap Part

\begin{tabular}{|c|c|c|c|}
\hline Part & $\begin{array}{c}\text { Steel } \\
\text { Fuel } \\
\text { Tank }\end{array}$ & $\begin{array}{c}\text { Side } \\
\text { Beam } \\
\text { Impact }\end{array}$ & $\begin{array}{c}\text { Wheel } \\
\text { Disc }\end{array}$ \\
\hline Pemasok & $\mathrm{S} 1$ & $\mathrm{~S} 2$ & $\mathrm{~S} 3$ \\
\hline Part & Seat & Door Trim & Lamp \\
\hline Pemasok & $\mathrm{S} 1$ & $\mathrm{~S} 2$ & $\mathrm{~S} 3$ \\
\hline Part & $\begin{array}{c}\text { Head- } \\
\text { lining }\end{array}$ & Insulator & Hose \\
\hline Pemasok & $\mathrm{S} 3$ & $\mathrm{~S} 1$ & $\mathrm{~S} 3$ \\
\hline
\end{tabular}

Tabel 6 menunjukkan perbandingan antara pemasok yang terplilh saat ini dan pemasok yang terpilih dengan metode usulan. Seperti terlihat bahwa Pemsok S3 saat ini hanya memasok satu part, sedangkan pada metode usulan memasok tiga buat part. Pemasok S3 memiliki nilai assessment yang cukup tinggi untuk kriteria Safety and Environmental Concern (SE), Delivery (DV) dan Capability (CB). Safety and Environmental Concern (SE) ini sangat perlu diperhatikan dalam produksi bersoh karena berkaitan dengan sistem dan penggiunaan material yang eco-friendly (Tektas \& Aytekin, 2011). Pemasok yang terpilih sudah meregistasikan material yang digunakan dalam International Material Data System (IMDS)

Selain itu, Pemasok S2 hampir memasok seluruh part yaitu tujuh dari sembilan part saat ini. Dengan menggunakan metode usulan, pemasok S2 hanya menyuplai dua part saja, Beralihnya pemilihan pemasok S2 ke pemasok 40
S1, karena pemasok S1 memiliki keunggulan penilaian pada kriteria Safety and Environmental Concern (SE), Delivery (DV) dan Capability (CB) dan Quality (QT). Selain Safety and Environmental Concern (SE), Quality (QT) merupakan kriteria yang penting bagi industri bersih karena part yang berkualitas dapat mengurangi produk cacat/waste.

Tabel 6. Perbandingan Pemasok Terpilih antara Metode Saat Ini dan Usulan untuk Setiap Part

\begin{tabular}{|c|c|c|}
\hline & \multicolumn{2}{|c|}{ Pemasok Terpilih } \\
\hline Parts & Saat ini & Usulan \\
\hline Steel Fuel Tank & $\mathrm{S} 2$ & $\mathrm{~S} 1$ \\
\hline $\begin{array}{c}\text { Side Beam } \\
\text { Impact }\end{array}$ & $\mathrm{S} 2$ & $\mathrm{~S} 2$ \\
\hline Wheel Disc & $\mathrm{S} 2$ & $\mathrm{~S} 2$ \\
\hline Seat & $\mathrm{S} 2$ & $\mathrm{~S} 1$ \\
\hline Door Trim & $\mathrm{S} 1$ & $\mathrm{~S} 2$ \\
\hline Lamp & $\mathrm{S} 2$ & $\mathrm{~S} 3$ \\
\hline Headlining & $\mathrm{S} 2$ & $\mathrm{~S} 3$ \\
\hline Insulator & $\mathrm{S} 2$ & $\mathrm{~S} 1$ \\
\hline Hose & $\mathrm{S} 3$ & $\mathrm{~S} 3$ \\
\hline
\end{tabular}

\section{Kesimpulan}

Penelitian ini dilakukan untuk menentukan kriteria dan subkriteria pemilihan pemasok berdasarkan kinerja pemasok dengan mempertimbangkan "green manufacturing". Dalam penelitian berhasil didapatkan tujuh kriteria digunakan dalam proses pemilihan pemasok, yaitu Biaya, Profil Perusahaan, Masalah Keselamatan dan Lingkungan, Pengiriman, Kemampuan, Kualitas, dan Layanan (Cost, Company Profile, Safety and Environmental Concern, Delivery, Capability, Quality, and Service). Setiap kriteria memiliki beberapa sub-kriteria.

Penelitian ini menggunakan metode FuzzyAHP dan ELECTRE. Fuzzy-AHP digunakan untuk menentukan bobot untuk kriteria dan sub-kriteria untuk mengurangi ketidakpastian dan ketidakjelasan informasi, sedangkan metode ELECTRE digunakan untuk menentukan peringkat pemasok dalam proses pemilihan. Fuzzy-AHP dan ELECTRE akan mengurangi ketidakpastian, keputusan subyektif dan meningkatkan akurasi pemasok yang dipilih.

Dalam penelitian, pemasok yang terpilih memiliki penilaian yang lebih unggul terhadap pemasok lainnya terutama dalam kriteria Safety and Environmental Concern (SE) dan 
Quality (QT) yang berkaitan dengan ramah lingkungan, lingkungan kerja yang aman/zero accident dan penghematan waste. Dalam hal ini pemasok harus membuktikan dengan sertifikat ISO14001.

Rekomendasi untuk penelitian selanjutnya adalah untuk mempertimbangkan kriteria pemasok hijau seperti limbah oleh produk dan penipisan sumber daya alam sebagai salah satu kriteria untuk penelitian masa depan.

\section{Daftar Pustaka}

Ayhan, M. B. (2013). A Fuzzy AHP Approach for Supplier Selection Problem: A Case Study in A Gear Motor Company, International Journal of Managing Value and SupplyChain, 4(3), pp. 11-23. https://www.researchgate.net/publication/25 8424309 A_Fuzzy_AHP_Approach_for_Su pplier_Selection_Problem_A_Case_Study_i n_a Gear Motor_Company

Beskase, A., dan Sakra, A., A (2010). Model Proposal For Supplier Selection in Automotive Industry, 14th International Research/Expert Conference, pp. 809-812. http://citeseerx.ist.psu.edu/viewdoc/downlo $\mathrm{ad}$ ?doi=10.1.1.403.2302\&rep=rep1\&type $=p$ df

Chand, M., Raj, T., Shankar, R., dan Agarwal, A., Select the Best Supply Chain by Risk Analysis for Indian Industries Environment Using MCDM Approaches, Benchmarking An International Journal, 24(5), 2017, pp. 1400-1413.

https://www.researchgate.net/publication/31 7046380_Select the best_supply_chain_b y_risk_analysis_for_Indian_industries_envir onment using_MCDM_approaches

Chan, F. T., Kumar, N., Tiwari, M. K., Lau, H. C. W., dan Choy, K. L., Global Supplier Selection: A Fuzzy-AHP, International Journal of Production Research, 46(14), 2008, pp. 3825-3857. https://www.tandfonline.com/doi/abs/10.108 0/00207540600787200

Charilas, D. E., Marzaki, O. I., Psarras, J., dan Constantinou, P., Application of Fuzzy AHP and ELECTRE to Network Selection, Mobile Lightweight Wireless Systems, 2009, pp. 63-73. https://link.springer.com/chapter/10.1007/97 8-3-642-03819-8_7

Cheraghi, S. H., Dadashzadeh, M., dan Subramanian, M., (2004). Critical Success
Factors For Supplier Selection: An Update, Journal of Applied Business Research, 20(2),pp. 91-108. https://clutejournals.com/index.php/JABR/ar ticle/view/2209

Dickson, G., (1966). An Analysis of Vendor Selection Systems and Decisions, Journal of Purchasing, 2(1), pp. 5-17. https://onlinelibrary.wiley.com/doi/abs/10.11 11/j.1745-493X.1966.tb00818.x

Ebrahimipour, V., Shoja, B. M., dan Li, S., (2016), Supplier Selection Considering Product Structure and Product Life Cycle Cost, International Journal of Quality \& Reliability Management, 33(5), pp. 654-675. https://www.emerald.com/insight/content/do i/10.1108/IJQRM-05-2015-0069/full/html

Govindan, K., dan Jepsen, M. B., (2016) ELECTRE: A Comprehensive Literature Review on Methodologies and Applications, European Journal of Operational Research, 250(1), pp. 1-29. https://portal.findresearcher.sdu.dk/en/publi cations/electre-a-comprehensive-literaturereview-on-methodologies-and-ap

Jiang, dkk. (2018) Green supplier selection for sustainable development of the automotive industry using grey decision-making. Sustainable Development, p.1-14.

https://www.researchgate.net/publication/3262 95723 Green_supplier_selection_for_susta inable_development_of the_automotive_in dustry_using_grey_decision-making

Kahraman, G., Gebeci, U., dan Ulukan, Z., (2003). Multi-Criteria Supplier Selection Using Fuzzy AHP, Logistics Information Management, 16(6), pp. 382-394. https://www.emerald.com/insight/content/do i/10.1108/09576050310503367/full/html?af $=R$

Nukman, Y., Farooqi A, Al-Sultan, O., Rahman, A., Alnasse, A., dan Bhuiyan , M.S.H, (2017). A Strategic Development of Green Manufacturing Index (GMI) Topology Concerning the Environmental Impacts, Procedia Engineering, 184, pp. $370-$ 380.

https://www.sciencedirect.com/science/artic le/pii/S1877705817316120

Pal, O., Gupta, A. K., dan Garg, R. K., (2013). Supplier Selection Criteria and methods in Supply Chains: A Review, International Journal of Economics and Management Engineering, $7(10), \quad$ pp. 2667-2673. 
https://pdfs. semanticscholar.org/1e2a/b757 c752f62d63252f4676232b8018c9e832.pdf

Paul, I.D., Bhole, G,P., \& Chaulhari, J.R. (2014). A Review on Green Manufacturing: It's Important, Methodology and its Application. Procedia Materials Science, Vol.6 p.1644-1649. https://www.researchgate.net/publication/27 3844357_A_Review_on_Green_Manufactu ring_It's_Important_Methodology_and_its_ Application

Thakker, S.V, \& Rane, S.B. (2018). Implementation of green supplier development process model in Indian automobile industry. Management of Environmental Quality: An International Journal , Vol. 29(5), pp. 938-960. https://www.researchgate.net/publication/32 6196257 Implementation_of_green_suppli er_development_process_model_in_Indian automobile industry

Tektas, A., dan Aytekin, A., Supplier Selection in the International Environment: A Comparative Case of a Turkish and an Australian Company, IBIMA Publishing, 2011, pp. 1-14. https://ibimapublishing.com/articles/IBIMAB R/2011/598845/598845.pdf

Thun, J. H., Druke, M., dan Grubner, A., Empowering Kanban through TPSPrinciples, International Journal of Production Research, 48(23), 2010, pp. 7089-7106. https://www.tandfonline.com/doi/abs/10.108 0/00207540903436695?scroll=top\&needAc cess=true\&journalCode=tprs20

Tidwell, A., dan Sutterfield, J. S., Supplier Selection Using QFD: A Consumer Products Case Study, Journal of Quality \& Reliability Management, 29(3), 2012, pp. 284-294.

https://www.researchgate.net/publication/26 3388180 Supplier_selection_using_QFD_A consumer products case study

Weber, C., Current, J., dan Benton, W., Vendor Selection Criteria and Methods, European Journal of Operational Research, 50(1), 1991, pp. 2-18. https://www.sciencedirect.com/science/artic le/abs/pii/037722179190033R

Yadav, V., dan Sharma, M. K., An Application of Hybrid Data Envelopment Analytical Hierarchy Process Approach for Supplier Selection, Journal of Enterprise Information Management, 28(2), 2015, pp. 218-242. https://www.emerald.com/insight/content/do i/10.1108/JEIM-04-2014-0041/full/html

Yadav, V., dan Sharma, M. K., Multi-Criteria Supplier Selection Model Using the Analytic Hierarchy Process Approach, Journal of Modelling in Management, 11(1), 2016, pp. 326-354.

https://www.emerald.com/insight/content/do i/10.1108/JM2-06-2014-0052/full/html 
Lampiran A. Data Matrik Pemasok

\begin{tabular}{|c|c|c|c|c|c|c|c|c|c|c|c|c|c|c|c|c|c|c|c|c|}
\hline \multicolumn{21}{|c|}{ Steel Fuel Tank Part } \\
\hline Kriteria & \multicolumn{2}{|c|}{ Cost } & \multicolumn{4}{|c|}{ Company Profile } & \multicolumn{4}{|c|}{ Safety \& Environmental } & \multicolumn{2}{|c|}{ Delivery } & \multicolumn{3}{|c|}{ Capability } & \multicolumn{3}{|c|}{ Quality } & \multicolumn{2}{|c|}{ Service } \\
\hline $\begin{array}{c}\text { Sub- } \\
\text { Kriteria }\end{array}$ & F1 & F2 & CP1 & CP2 & CP3 & CP4 & SE1 & SE2 & SE3 & SE4 & DV1 & DV2 & CB1 & CB2 & CB3 & Q1 & Q2 & Q3 & SV1 & SV2 \\
\hline S1 & 2 & 1 & 1 & 10 & 10 & 4 & 10 & 10 & 10 & 8 & 1 & 2 & 2 & 6 & 4 & 6 & 6 & 10 & 10 & 1 \\
\hline $\mathrm{S} 2$ & 8 & 1 & 1 & 1 & 10 & 8 & 1 & 10 & 10 & 8 & 1 & 1 & 1 & 6 & 2 & 1 & 2 & 10 & 5 & 5 \\
\hline \multicolumn{21}{|c|}{ Side Beam Impact Part } \\
\hline Kriteria & \multicolumn{2}{|c|}{ Cost } & \multicolumn{4}{|c|}{ Company Profile } & \multicolumn{4}{|c|}{ Safety \& Environmental } & \multicolumn{2}{|c|}{ Delivery } & \multicolumn{3}{|c|}{ Capability } & & Qualit & & $\mathrm{Sel}$ & \\
\hline $\begin{array}{c}\text { Sub- } \\
\text { Kriteria }\end{array}$ & $\mathrm{F} 1$ & F2 & CP1 & CP2 & CP3 & CP4 & SE1 & SE2 & SE3 & SE4 & DV1 & DV2 & CB1 & CB2 & CB3 & Q1 & Q2 & Q3 & SV1 & SV2 \\
\hline S1 & 1 & 1 & 8 & 5 & 10 & 10 & 10 & 10 & 10 & 8 & 4 & 1 & 8 & 8 & 8 & 2 & 2 & 10 & 10 & 5 \\
\hline S2 & 1 & 4 & 6 & 10 & 10 & 6 & 10 & 10 & 1 & 8 & 8 & 1 & 10 & 10 & 10 & 8 & 10 & 10 & 5 & 10 \\
\hline & & & & & & & & & Whee & Disc I & & & & & & & & & & \\
\hline Kriteria & $C$ & & & Compa & y Profi & & & ety \&E & vironm & & Del & ery & & apabil & & & Qualit & & $\mathrm{Sel}$ & \\
\hline $\begin{array}{c}\text { Sub- } \\
\text { Kriteria }\end{array}$ & $\mathrm{F} 1$ & F2 & CP1 & $\mathrm{CP} 2$ & $\mathrm{CP} 3$ & $\mathrm{CP} 4$ & SE1 & SE2 & SE3 & SE4 & DV1 & DV2 & CB1 & CB2 & CB3 & Q1 & Q2 & Q3 & SV1 & SV2 \\
\hline $\mathrm{S1}$ & 8 & 4 & 8 & 5 & 10 & 1 & 10 & 10 & 10 & 4 & 2 & 10 & 1 & 1 & 4 & 1 & 1 & 10 & 1 & 5 \\
\hline S2 & 8 & 2 & 6 & 10 & 10 & 10 & 10 & 10 & 1 & 8 & 8 & 1 & 10 & 10 & 8 & 8 & 2 & 10 & 10 & 5 \\
\hline S3 & 10 & 2 & 10 & 10 & 10 & 10 & 10 & 10 & 1 & 8 & 1 & 1 & 1 & 8 & 4 & 1 & 6 & 10 & 10 & 10 \\
\hline & & & & & & & & & & tPan & & & & & & & & & & \\
\hline Kriteria & $C$ & sst & & Compa & $y$ Profil & & & ty \&E & vironm & & $D e$ & ery & & apabil & & & Qualit, & & $\mathrm{Sel}$ & \\
\hline $\begin{array}{c}\text { Sub- } \\
\text { Kriteria }\end{array}$ & F1 & F2 & CP1 & CP2 & CP3 & CP4 & SE1 & SE2 & SE3 & SE4 & DV1 & DV2 & CB1 & CB2 & CB3 & Q1 & Q2 & Q3 & SV1 & SV2 \\
\hline $\mathrm{S} 1$ & 1 & 2 & 8 & 10 & 10 & 10 & 10 & 10 & 10 & 8 & 2 & 2 & 2 & 6 & 4 & 6 & 6 & 10 & 10 & 5 \\
\hline $\mathrm{S} 2$ & 2 & 4 & 10 & 5 & 10 & 6 & 10 & 10 & 10 & 8 & 1 & 1 & 1 & 6 & 2 & 1 & 2 & 10 & 5 & 5 \\
\hline & & & & & & & & & Door & Trim $F$ & & & & & & & & & & \\
\hline Kriteria & $C$ & sst & & Compa & $y$ Profi & & & ty \&E & vironm & & $D e$ & ery & & apabil & & & Qualit & & $\mathrm{Sel}$ & \\
\hline $\begin{array}{c}\text { Sub- } \\
\text { Kriteria }\end{array}$ & $\mathrm{F} 1$ & F2 & CP1 & CP2 & CP3 & CP4 & SE1 & SE2 & SE3 & SE4 & DV1 & DV2 & CB1 & CB2 & CB3 & Q1 & Q2 & Q3 & SV1 & SV2 \\
\hline $\mathrm{S} 1$ & 2 & 4 & 8 & 10 & 10 & 10 & 10 & 10 & 10 & 8 & 1 & 1 & 1 & 6 & 6 & 1 & 4 & 10 & 10 & 10 \\
\hline S2 & 1 & 2 & 10 & 10 & 10 & 10 & 10 & 10 & 10 & 10 & 10 & 4 & 10 & 10 & 8 & 8 & 10 & 10 & 10 & 10 \\
\hline S3 & 1 & 2 & 10 & 10 & 6 & 4 & 10 & 10 & 10 & 8 & 10 & 8 & 8 & 4 & 4 & 2 & 2 & 10 & 1 & 10 \\
\hline & & & & & & & & & & pp Pal & & & & & & & & & & \\
\hline Kriteria & C & sst & & Compa & y Profi & & & ty \&E & vironm & & Del & ery & & apabil & & & Qualit & & $\mathrm{Sel}$ & \\
\hline $\begin{array}{c}\text { Sub- } \\
\text { Kriteria }\end{array}$ & $\mathrm{F} 1$ & F2 & CP1 & CP2 & CP3 & CP4 & SE1 & SE2 & SE3 & SE4 & DV1 & DV2 & CB1 & CB2 & CB3 & Q1 & Q2 & Q3 & SV1 & SV2 \\
\hline S1 & 1 & 6 & 10 & 10 & 6 & 10 & 10 & 10 & 10 & 8 & 10 & 2 & 1 & 4 & 4 & 4 & 2 & 10 & 10 & 10 \\
\hline $\mathrm{S} 2$ & 2 & 8 & 6 & 10 & 4 & 6 & 10 & 10 & 1 & 6 & 4 & 1 & 1 & 6 & 6 & 6 & 2 & 10 & 10 & 5 \\
\hline S3 & 1 & 2 & 2 & 10 & 6 & 4 & 10 & 10 & 1 & 10 & 10 & 2 & 10 & 6 & 4 & 1 & 2 & 10 & 10 & 10 \\
\hline & & & & & & & & & Head & ining $\mathrm{f}$ & & & & & & & & & & \\
\hline Kriteria & $\mathrm{C}$ & & & Compa & Profil & & & ty \&E & vironm & & Del & ery & & apabili & & & 2ualit & & Ser & \\
\hline $\begin{array}{c}\text { Sub- } \\
\text { Kriteria }\end{array}$ & $\mathrm{F} 1$ & F2 & CP1 & CP2 & CP3 & CP4 & SE1 & SE2 & SE3 & SE4 & DV1 & DV2 & CB1 & CB2 & CB3 & Q1 & Q2 & Q3 & SV1 & SV2 \\
\hline S1 & 1 & 2 & 2 & 10 & 10 & 10 & 10 & 10 & 1 & 8 & 1 & 1 & 2 & 8 & 8 & 8 & 4 & 10 & 10 & 10 \\
\hline S2 & 1 & 4 & 6 & 10 & 10 & 10 & 10 & 10 & 1 & 8 & 6 & 2 & 1 & 8 & 8 & 6 & 1 & 10 & 10 & 10 \\
\hline S3 & 1 & 1 & 8 & 10 & 4 & 10 & 10 & 10 & 10 & 8 & 10 & 10 & 10 & 8 & 8 & 10 & 1 & 10 & 5 & 10 \\
\hline & & & & & & & & & Dash & Insula & & & & & & & & & & \\
\hline Kriteria & $C$ & stt & & Compa & $y$ Profi & & & ty \&E & vironm & & $D e$ & ery & & apabil & & & 2ualit & & $\mathrm{Sel}$ & \\
\hline $\begin{array}{c}\text { Sub- } \\
\text { Kriteria }\end{array}$ & F1 & F2 & CP1 & CP2 & CP3 & CP4 & SE1 & SE2 & SE3 & SE4 & DV1 & DV2 & CB1 & CB2 & CB3 & Q1 & Q2 & Q3 & SV1 & SV2 \\
\hline S1 & 4 & 2 & 6 & 10 & 10 & 10 & 10 & 10 & 1 & 8 & 6 & 1 & 1 & 8 & 6 & 6 & 6 & 10 & 10 & 10 \\
\hline S2 & 8 & 8 & 4 & 5 & 4 & 10 & 5 & 10 & 10 & 8 & 8 & 1 & 1 & 6 & 4 & 1 & 2 & 10 & 10 & 5 \\
\hline & & & & & & & & & & se $P a r$ & & & & & & & & & & \\
\hline Kriteria & $C$ & sst & & Compa & y Profi & & & ty \&E & vironm & & Del & ery & & Tapabil & & & Qualit & & $\mathrm{Sel}$ & \\
\hline $\begin{array}{c}\text { Sub- } \\
\text { Kriteria }\end{array}$ & F1 & F2 & CP1 & CP2 & CP3 & CP4 & SE1 & SE2 & SE3 & SE4 & DV1 & DV2 & CB1 & CB2 & CB3 & Q1 & Q2 & Q3 & SV1 & SV2 \\
\hline S1 & 10 & 2 & 6 & 5 & 2 & 4 & 1 & 10 & 10 & 4 & 1 & 1 & 1 & 4 & 1 & 1 & 1 & 10 & 5 & 5 \\
\hline $\mathrm{S} 2$ & 10 & 2 & 2 & 10 & 10 & 10 & 10 & 10 & 10 & 6 & 1 & 2 & 1 & 8 & 4 & 1 & 4 & 10 & 5 & 10 \\
\hline S3 & 10 & 2 & 8 & 10 & 8 & 6 & 10 & 10 & 10 & 8 & 10 & 1 & 10 & 6 & 6 & 10 & 1 & 10 & 5 & 5 \\
\hline
\end{tabular}


Lampiran B. Outrankings Relationship

\begin{tabular}{|c|c|c|c|c|c|c|c|c|}
\hline & $\begin{array}{l}\text { Concordance } \\
\text { Index }\end{array}$ & $\begin{array}{c}> \\
\mathrm{C}^{*} \text { Threshold }\end{array}$ & Judge & & $\begin{array}{l}\text { Discordance } \\
\text { Index }\end{array}$ & $\begin{array}{c}< \\
D^{*} \text { Threshold }\end{array}$ & Judge. & $\begin{array}{c}\text { Pemasok } \\
\text { Terpilih }\end{array}$ \\
\hline \multicolumn{9}{|c|}{ Steel Fuel Tank } \\
\hline $\mathrm{C}(1,2)$ & 0.9374 & 0.709 & Yes & $\mathrm{D}(1,2)$ & 0.1278 & 0.5639 & Yes & \multirow{2}{*}{ S1 } \\
\hline $\mathrm{C}(2,1)$ & 0.4805 & 0.709 & No & $\mathrm{D}(2,1)$ & 1 & 0.5639 & No & \\
\hline \multicolumn{9}{|c|}{ Side Beam Impact } \\
\hline $\mathrm{C}(1,2)$ & 0.4116 & 0.6754 & No & $\mathrm{D}(1,2)$ & 1 & 0.5998 & No & \multirow{2}{*}{$\mathrm{S} 2$} \\
\hline $\mathrm{C}(2,1)$ & 0.9392 & 0.6754 & Yes & $\mathrm{D}(2,1)$ & 0.1996 & 0.5998 & Yes & \\
\hline \multicolumn{9}{|c|}{ Wheel Disc } \\
\hline $\mathrm{C}(1,2)$ & 0.4116 & 0.6754 & No & $\mathrm{D}(1,2)$ & 1 & 0.5998 & No & \multirow{6}{*}{ S2 } \\
\hline$C(1,3)$ & 0.9058 & 0.6754 & Yes & $\mathrm{D}(1,3)$ & 0.0512 & 0.5998 & Yes & \\
\hline $\mathrm{C}(2,1)$ & 0.9121 & 0.6754 & Yes & $\mathrm{D}(2,1)$ & 0.104 & 0.5998 & Yes & \\
\hline $\mathrm{C}(2,3)$ & 0.9121 & 0.6754 & Yes & $\mathrm{D}(2,3)$ & 0.0123 & 0.5998 & Yes & \\
\hline $\mathrm{C}(3,1)$ & 0.0942 & 0.6754 & No & $\mathrm{D}(3,1)$ & 1 & 0.5998 & No & \\
\hline $\mathrm{C}(3,2)$ & 0.0608 & 0.6754 & No & $\mathrm{D}(3,2)$ & 1 & 0.5998 & No & \\
\hline \multicolumn{9}{|c|}{ Seat } \\
\hline $\mathrm{C}(1,2)$ & 0.9591 & 0.6564 & Yes & $\mathrm{D}(1,2)$ & 0.1282 & 0.5641 & Yes & \multirow{2}{*}{ s1 } \\
\hline $\mathrm{C}(2,1)$ & 0.3538 & 0.6564 & No & $\mathrm{D}(2,1)$ & 1 & 0.5641 & No & \\
\hline \multicolumn{9}{|c|}{ Door Trim } \\
\hline $\mathrm{C}(1,2)$ & 0.2939 & 0.6554 & No & $\mathrm{D}(1,2)$ & 1 & 0.6826 & No & \multirow{6}{*}{ S2 } \\
\hline$C(1,3)$ & 0.494 & 0.6554 & No & $\mathrm{D}(1,3)$ & 1 & 0.6826 & No & \\
\hline $\mathrm{C}(2,1)$ & 0.9592 & 0.6554 & Yes & $\mathrm{D}(2,1)$ & 0.2371 & 0.6826 & Yes & \\
\hline $\mathrm{C}(2,3)$ & 0.8882 & 0.6554 & Yes & $\mathrm{D}(2,3)$ & 0.5915 & 0.6826 & Yes & \\
\hline $\mathrm{C}(3,1)$ & 0.7708 & 0.6554 & Yes & $\mathrm{D}(3,1)$ & 0.2672 & 0.6826 & Yes & \\
\hline $\mathrm{C}(3,2)$ & 0.5257 & 0.6554 & No & $\mathrm{D}(3,2)$ & 1 & 0.6826 & No & \\
\hline \multicolumn{9}{|c|}{ Lamp } \\
\hline $\mathrm{C}(1,2)$ & 0.7511 & 0.7252 & Yes & $\mathrm{D}(1,2)$ & 0.4719 & 0.717 & Yes & \multirow{4}{*}{ S3 } \\
\hline $\mathrm{C}(1,3)$ & 0.7737 & 0.7252 & Yes & $\mathrm{D}(1,3)$ & 1 & 0.717 & No & \\
\hline $\mathrm{C}(2,1)$ & 0.647 & 0.7252 & No & $\mathrm{D}(2,1)$ & 1 & 0.717 & No & \\
\hline$C(2,3)$ & 0.5423 & 0.7252 & No & $\mathrm{D}(2,3)$ & 1 & 0.717 & No & \\
\hline $\mathrm{C}(3,1)$ & 0.8389 & 0.7252 & Yes & $\mathrm{D}(3,1)$ & 0.2081 & 0.717 & Yes & \multirow{2}{*}{ S3 } \\
\hline $\mathrm{C}(3,2)$ & 0.7982 & 0.7252 & Yes & $\mathrm{D}(3,2)$ & 0.6219 & 0.717 & Yes & \\
\hline \multicolumn{9}{|c|}{ Headlining } \\
\hline $\mathrm{C}(1,2)$ & 0.7096 & 0.6963 & Yes & $\mathrm{D}(1,2)$ & 1 & 0.6763 & No & \multirow{6}{*}{ S3 } \\
\hline$C(1,3)$ & 0.4668 & 0.6963 & No & $\mathrm{D}(1,3)$ & 1 & 0.6763 & No & \\
\hline $\mathrm{C}(2,1)$ & 0.705 & 0.6963 & Yes & $\mathrm{D}(2,1)$ & 0.5891 & 0.6763 & Yes & \\
\hline $\mathrm{C}(2,3)$ & 0.4668 & 0.6963 & No & $\mathrm{D}(2,3)$ & 1 & 0.6763 & No & \\
\hline $\mathrm{C}(3,1)$ & 0.8876 & 0.6963 & Yes & $\mathrm{D}(3,1)$ & 0.3273 & 0.6763 & Yes & \\
\hline $\mathrm{C}(3,2)$ & 0.942 & 0.6963 & Yes & $\mathrm{D}(3,2)$ & 0.1417 & 0.6763 & Yes & \\
\hline \multicolumn{9}{|c|}{ Dash Insulator } \\
\hline $\mathrm{C}(1,2)$ & 0.7784 & 0.7209 & Yes & $\mathrm{D}(1,2)$ & 0.0883 & 0.5639 & Yes & \multirow{2}{*}{ S1 } \\
\hline $\mathrm{C}(2,1)$ & 0.6634 & 0.7209 & No & $\mathrm{D}(1,3)$ & 1 & 0.5639 & No & \\
\hline \multicolumn{9}{|c|}{ Hose } \\
\hline $\mathrm{C}(1,2)$ & 0.613 & 0.7153 & No & $\mathrm{D}(1,2)$ & 1 & 0.5559 & No & \multirow{6}{*}{ S3 } \\
\hline$C(1,3)$ & 0.3997 & 0.7153 & No & $\mathrm{D}(1,3)$ & 1 & 0.5559 & No & \\
\hline $\mathrm{C}(2,1)$ & 0.9999 & 0.7153 & Yes & $\mathrm{D}(2,1)$ & 0.0008 & 0.5559 & Yes & \\
\hline $\mathrm{C}(2,3)$ & 0.508 & 0.7153 & No & $\mathrm{D}(2,3)$ & 1 & 0.5559 & No & \\
\hline $\mathrm{C}(3,1)$ & 1 & 0.7153 & Yes & $\mathrm{D}(3,1)$ & 0 & 0.5559 & Yes & \\
\hline $\mathrm{C}(3,2)$ & 0.7711 & 0.7153 & Yes & $\mathrm{D}(3,2)$ & 0.3346 & 0.5559 & Yes & \\
\hline
\end{tabular}

